\title{
KONSELING KELOMPOK UNTUK PENINGKATAN MOTIVASI BELAJAR DENGAN PENDEKATAN SFBC (TEKNIK MIRACLE QUESTION)
}

\author{
Tega Wijayanti \\ SMA Hang Tuah 1 Surabaya \\ tegawsetyono12@gmail.com
}

\begin{abstract}
Motivation to learn is something to stimulate students in carrying out learning activities to get a goal, namely achievement in learning. In learning activities, there will be active interactions that lead to the physical and mental development of students. So the authors conducted research on "Group Counseling To Increase Learning Motivation With SFBC (Miracle Question Technique) Approach To Students Class XI IPA 2 SMA Hang Tuah 1 Surabaya". The aim was to see if the SFBC approach to magic questioning techniques had an effect on increasing learning motivation. Retrieval of research subjects was carried out using data methods in the form of measuring learning motivation, data from interviews with subject teachers about the conditions of students' activeness during learning activities, activeness in carrying out assignments, and the accuracy of task orders. Based on the descriptive analysis, the proportion of large motivation to learn in class XI IPA 2 is $5.56 \%$ has very high learning motivation, $30.56 \%$ has high learning motivation, $47.22 \%$ has moderate learning motivation, and $16.67 \%$ has low motivation to learn. The author tries to help increase motivation to learn with the magic question technique because the essence of every human being is able to build solutions to improve his life. The author seeks to help students to find solutions with barriers, strengths, and weaknesses themselves. Because the learning motivation factor is the dominant factor, it is sought for further research to analyze the factors that influence learning motivation, for example learning environments, learning resources and learning media.
\end{abstract}

\section{ABSTRAK}

Motivasi belajar adalah sesuatu hal untuk merangsang peserta didik dalam melakukan aktifitas belajar untuk mendapatkan suatu tujuan yaitu prestasi dalam belajar. Dalam kegiatan belajar akan terjadi interaksi aktif yang mengarah pada perkembangan fisik dan mental peserta didik. Maka penulis bersemangat untuk melakukan penelitian tentang "Konseling Kelompok Untuk Peningkatan Motivasi Belajar Dengan Pendekatan SFBC (Teknik Miracle Question) Pada Peserta Didik Kelas XI IPA 2 SMA Hang Tuah 1 Surabaya". Tujuannya adalah untuk mengetahui apakah pendekatan SFBC teknik miracle question berpengaruh untuk peningkatan motivasi belajar. Pengambilan subyek penelitian dilakukan dengan metode pengumpulan data berupa skala pengukuran motivasi belajar, data hasil wawancara dengan guru mata pelajaran tentang kondisi keaktifan peserta didik selama mengikuti kegiatan belajar, keaktifan mengerjakan tugas dan ketepatan pengumpulan tugas. Berdasarkan analisis deskriptif persentase diperoleh besarnya motivasi belajar di kelas XI IPA 2 adalah 5,56\% memiliki motivasi belajar sangat tinggi, 30,56\% memiliki motivasi belajar yang tinggi, 47,22\% memiliki motivasi belajar yang sedang, dan 16,67\% memiliki motivasi belajar yang rendah. Penulis berupaya membantu meningkatkan motivasi belajar dengan teknik miracle question karena hakikat setiap manusia mampu membangun solusi untuk memperbaiki kehidupannya. Penulis berupaya membantu peserta didik untuk menemukan solusi dengan mengenali hambatan, kekuatan dan kelemahan diri. Karena faktor motivasi belajar bukanlah faktor yang dominan, maka disarankan untuk penelitian selanjutnya mencoba meneliti faktor-faktor yang mempengaruhi motivasi belajar, misalnya lingkungan belajar, sumber belajar dan media belajar.

Kata Kunci perilaku asertif, asertive training, konseling kelompok 
Cara mengutip: Wijayanti, T. (2020). Konseling Kelompok Untuk Peningkatan Motivasi Belajar Dengan Pendekatan SFBC (Teknik Miracle Question). Nusantara of Research : Jurnal Hasil-Hasil Penelitian Universitas Nusantara PGRI Kediri (e-Journal), 7(2), 106-114. https://doi.org/10.29407/nor.v7i2.15063

\section{PENDAHULUAN}

Berdasarkan observasi yang telah dilakukan selama kegiatan belajar mengajar di SMA Hang Tuah 1 Surabaya pada bulan Agustus 2020, Kegiatan belajar mengajar sudah berjalan dengan baik, karena didukung guru-guru yang kompeten terhadap tugas dan tanggung jawabnya, fasilitas belajar juga sudah dapat menunjang efektivitas belajar di sekolah, serta fasilitas penunjang kegaitan belajar antara lain sebagai berikut, ruang kelas, media belajar dan sumber belajar yang lengkap seperti buku bacaan, buku Latihan soal, jaringan internet, laboratorium, perpustakaan dan peralatan elektronik audio visual. Selain itu diluar jam pelajaran juga dilakukan bimbingan belajar yang terjadwal. Semua fasilitas pendukung kegiatan belajar di SMA Hang Tuah 1 Surabaya sangat menunjang keefektifan kegiatan belajar mengajar serta menciptakan motivasi belajar tinggi sehingga para siswa bisa mendapatkan hasil belajar yang baik sesuai dengan tuntutan sekolah.

Namun kondisi kenyataan di lapangan tidak sepenuhnya sesuai dengan hasil observasi, setelah dilakukan penilaian lebih lanjut dengan menggunakan pedoman observasi motivasi belajar didapatkan sebuah kondisi sekitar $27 \%$ siswa masih memiliki motivasi belajarnya pada kategori rendah, penilaian ini juga didukung dengan observasi langsung pada dari sikap dan perilaku peserta didik, dimana peserta didik yang termasuk dalam kategori memiliki motivasi belajar rendah memiliki sikap malas saat kegiatan belajar, seringkali melalaikan pengerjaan tugas sekolah, kurang memperhatikan guru pada saat memberikan materi di kelas, sering gaduh dalam kegiatan belajar di kelas, sering tidak mengikuti pelajaran, sering tidak hadir di kelas bimbel, sehingga mereka mendapatkan hasil belajar yang kurang atau dibawah nilai ketuntasan minimal yang sudah diterapkan di sekolah.

Kondisi peserta didik yang memiliki motivasi belajar rendah ini secara langsung membuat hasil belajarnya yang kurang memuaskan. Hal ini merupakan suatu masalah belajar karena peserta didik memiliki kemungkinan untuk mendapatkan hasil prestasi belajar yang lebih baik. Gejala ini sangat berkaitan dengan banyak aspek, seperti tingkat motivasi, minat setiap peserta didik, sikap dan kebiasaan-kebiasaan belajar yang mereka terapkan sehari-hari.

Bimbingan dan konseling merupakan salah satu bagian dari sistem Pendidikan yang berguna dalam memfasilitasi perkembangan pada peserta didik, sehingga tugas guru Bimbingan dan Konseling adalah memandirikan peserta didik dalam rangka mencapai perkembangan yang utuh dan optimal sesuai dalam Permendikbud nomor 111/2014. Oleh karena itu guru Bimbingan dan Konseling harus memberikan bimbingan yang sesuai untuk membantu peserta didik menyelesaikan masalah-masalahnya tersebut.

Permasalahan rendahnya motivasi belajar yang dialami peserta didik di SMA Hang Tuah 1 Surabaya, sebagai guru Bimbingan dan Konseling kita dituntut untuk mampu membantu mengentaskan masalah yang dialami peserta didik tersebut dengan memberikan bimbingan berupa layanan konseling kelompok, karena dalam kegiatan layanan dengan pendekatan kelompok sangat efektif diterapkan karena akan memberikan stimulus bagi tiap anggota 
kelompok untuk mendapatkan manfaat dari berbagai informasi, berani memberikan tanggapan dan reaksi timbal balik dalam memberikan solusi untuk masalah yang dihadapi tiap anggota kelompok, dan juga melalui kegiatan kelompok seperti itu mendorong masing-masing individu dapat memunculkan sikap tenggang rasa, melatih kemampuan komunikasi, mengendalikan dan mengontrol ego sehingga masing-masing individu dapat berperan aktif secara langsung maupun tidak langsung dalam membantu memecahkan masalah Bersama-sama. Usaha yang dilakukan guna membantu peserta didik yang motivasi belajarnya dalam tingkatan rendah perlu diberikan pendekatan yang sesuai, peserta didik SMA Hang Tuah 1 Surabaya yang motivasi belajarnya dalam tingkatan yang rendah yakni masih sering melakukan Tindakan-tindakan yang tidak baik seperti malas belajar, masih tidak tertib dalam pengerjaan tugas dari guru, membuat suasana gaduh dikelas, tidak hadir dalam kegiatan belajar dan lain sebagainya, sementara itu fungsi dari motivasi belajar yang tinggi.

Motivasi belajar adalah sesuatu hal untuk merangsang peserta didik dalam melakukan aktifitas belajar untuk mendapatkan suatu tujuan yaitu prestasi dalam belajar. Dengan motivasi yang sangat kuat, maka kita akan belajar dengan bersemangat, tekun dan bersungguhsungguh. Namun, jika kita memiliki motivasi yang lemah maka kita akan bersikap malas dan enggan dalam mengerjakan tugas-tugas. Sedangkan motivasi dalam belajar menurut Omrood (2010) adalah sesuatu hal yang membuat mereka selalu bergerak, terarah, dan mampu mempertahankan perilaku-perilaku. Motivasi dapat memberikan stimulus agar siswa terus bergerak, memposisikan mereka dalam satu tujuan tertentu, dan menjaga agar mereka produktif.

Motivasi menurut Djamarah (2011) adalah gejala psikologis dalam bentuk dorongan yang timbul pada individu dalam suatu kondisi tertentu untuk melakukan suatu tindakan yang memiliki suatu tujuan. Suatu bentuk daya upaya yang membuat seseorang atau kelompok orang terus bergerak berkegiatan karena untuk mencapai suatu hasil yang sesuai dengan kemauan atau tujuan untuk mendapatkan kepuasan dengan usahanya tersebut. Kesimpulan dari motivasi belajar adalah suatu kegiatan daya upaya untuk memberi arah perilaku siswa sesuai dengan arah atau tujuan yang sesuai dengan kemauannya dan dipengaruhi oleh keadaan dari dalam diri sendiri (internal) maupun keadaan dari luar diri sendiri (eksternal). Prayitno dan Amti (2004) menjelaskan bahwa kegagalan yang dialami siswa dalam belajar tidak selalu disebabkan oleh faktor kebodohan atau rendahnya intelegensi. Kegagalan sering terjadi karena siswa tidak mendapatkan layanan belajar yang memadai.

Menurut Sardiman (2011) motivasi belajar merupakan kegiatan memberikan stimulus manusia untuk berbuat sebagai penggerak atau motor yang melepaskan energi. Setiap kegiatan yang dikerjakan merupakan hasil dari adanya motivasi. Sehingga arah tujuan yang ingin dicapai dapat dengan mudah ditentukan. Jadi motivasi dapat mengarahkan kegiatan-kegiatan yang harus dilaksanakan sesuai dengan tujuan yang ingin dicapai dengan peranan yang khas yaitu merasa bersemangat untuk mengikuti kegiatan belajar dan merasa senang. Sehingga peneliti tertarik untuk menerapkan model pendekatan konseling yaitu model pendekatan SFBC (Konseling Singkat Berbasis Solusi) yaitu pendekatan konseling dengan mengoptimalkan kemampuan peserta didik atau konseli untuk mencari jalan keluar atau solusi sehingga konseli 
akan memiliki kemampuan untuk memilih sendiri tujuan yang hendak ia capai (Corey, 2013). Berdasar pada uraian diatas, maka perlu diadakan penelitian tentang penerapan konseling konseling kelompok untuk peningkatan motivasi belajar peserta didik SMA Hang Tuah 1 Surabaya, dengan SFBC (Konseling Singkat Berbasis Solusi) teknik miracle question.

\section{METODE}

Penelitian ini merupakan penelitian tindakan Bimbingan Konseling dimana kegiatan penelitian yang sudah umum dan dikenal luas di kalangan praktisi Pendidikan yang memiliki manfaat untuk memperbaiki suatu kondisi khususnya di lingkungan sekolah sehingga dapat memberikan pemahaman-pemahaman baru dalam praktek bimbingan. Hopkins (2011), bahwa dalam kegiatan penelitian tindakan kelas harus menyusun perencanaan tindakan terlebih dahulu (Planning), kemudian ada penerapan tindakan yang dilaksanakan (action), kemudian melaksanakan observasi dan evaluasi proses maupun hasil tindakan (Observation and evaluation). Mekanisme kerja dalam suatu penelitian tindakan kelas terdiri dari empat komponen, antara lain adanya perencanaan (planning), adanya kegiatan pelaksanaan (acting), melakukan pengamatan (observing), dan melaksanakan refleksi kegiatan (reflecting), dan sehingga perbaikan atau peningkatan yang sesuai dengan tujuan dapat tercapai dengan baik (kriteria keberhasilan). Langkah-langkah dalam melaksanakan penelitian tindakan kelas antara lain: Menyusun Perencanaan (Planning), merupakan langkah awal dalam setiap kegiatan yaitu Menyusun rencana dan membuat media layanan yang akan diterapkan dalam kegiatan penelitian kelas. Pelaksanaan Tindakan (Acting), yaitu skenario tindakan yang akan diterapkan dalam kegiatan penelitian sesuai dengan prosedur yang akan diterapkan. Observasi (Observe) kegiatan ini dilaksanakan untuk melakukan pengamatan jalannya kegiatan penelitiannya sehingga dapat diketahui kendala-kendala yang ditemui yang dapat memberikan hasil yang tidak sesuai dengan tujuan. Refleksi (Reflecting), refleksi merupakan kegiatan evaluasi untuk mengamati hasil-hasil yang didapatkan dalam suatu kegiatan, sehingga dapat dijadikan tolak ukur dalam suatu kegiatan dalam menentukan kegiatan replanning.

Pelaksanaan penelitian ini di SMA Hang Tuah 1 Surabaya di JL. Ikan Lumba-lumba no.27 Surabaya. Penelitian melibatkan siswa kelas XI IPA 2. Waktu penelitian dilaksanakan pada bulan Agustus. Subyek penelitian adalah peserta didik kelas XI IPA 2 tahun pelajaran 2020/2021 sejumlah 36 peserta didik dengan rincian 15 putra dan 21 putri. Taraf kemampuan hasil belajar mereka dalam taraf sedang, dengan nilai hasil belajar cenderung rendah dan juga ada banyak catatan pelanggaran tata tertib pada saat proses belajar yaitu peserta didik sering tidak tepat waktu mengikuti kegiatan belajar, sering tidak tepat waktu dalam mengerjakan tugas dari guru, dan ada laporan dari guru mata pelajaran bahwa peserta didik sering gaduh sehingga kelas tidak kondusif, mengantuk pada saat guru menyampaikan materi. Teknik penggumpulan data yang digunakan yaitu observasi yang dilakukan pada saat kegiatan belajar berlangsung, wawancara dari guru mata pelajaran dilakukan untuk mengetahui sejauh mana keaktifan peserta didik dalam mengikuti pelajaran, dalam mengerjakan tugas-tugasnya dan ketepatan waktu pengumpulan tugas dan skala pengukuran motivasi belajar untuk mengukur sejauhmana tingkat motivasi belajarnya. 
HASIL

Pada penelitian ini semua kegiatan dilakukan dalam sistem daring karena belum diijinkan untuk melaksanakan pembelajaran tatap muka, setelah dilakukan pengumpulan data maka ada 6 peserta didik yang berada dalam kategori motivasi belajar yang rendah sesuai dengan hasil wawancara dan skala pengukuran motivasi belajar. Maka pelaksanaan penelitian tindakan kelas focus pada 6 peserta didik tersebut. Kegiatan layanan konseling kelompok dengan teknik miracle questions dilaksanakan dalam siklus I dan siklus II. Kegiatan layanan konseling kelompok, semua anggota kelompok di beri stimulus agar aktif dalam menyampaikan pendapat, mengetahui hambatan-hambatan dan kesulitan-kesulitan yang dialami selama mengikuti kegiatan belajar dan mereka didorong untuk mencari dan menggali solusinya sendiri dengan konnselor memberikan kalimat pertanyaan keajaiban. Kemudian diberi penguatan dengan melihat video motivasi dari tokoh-tokoh inspiratif. Selama melaksanakan siklus I dan siklus II peserta didik sudah memberikan kontribusi aktif dan apresiasi yang positif. Perubahan tingkat motivasi belajar nampak pada skala pengukuran motivasi yang diisi oleh peserta didik, dan peningkatan keaktifan peserta didik dalam mengikuti kegiatan belajar. Berikut grafik dari pra siklus, siklus I dan siklus II.

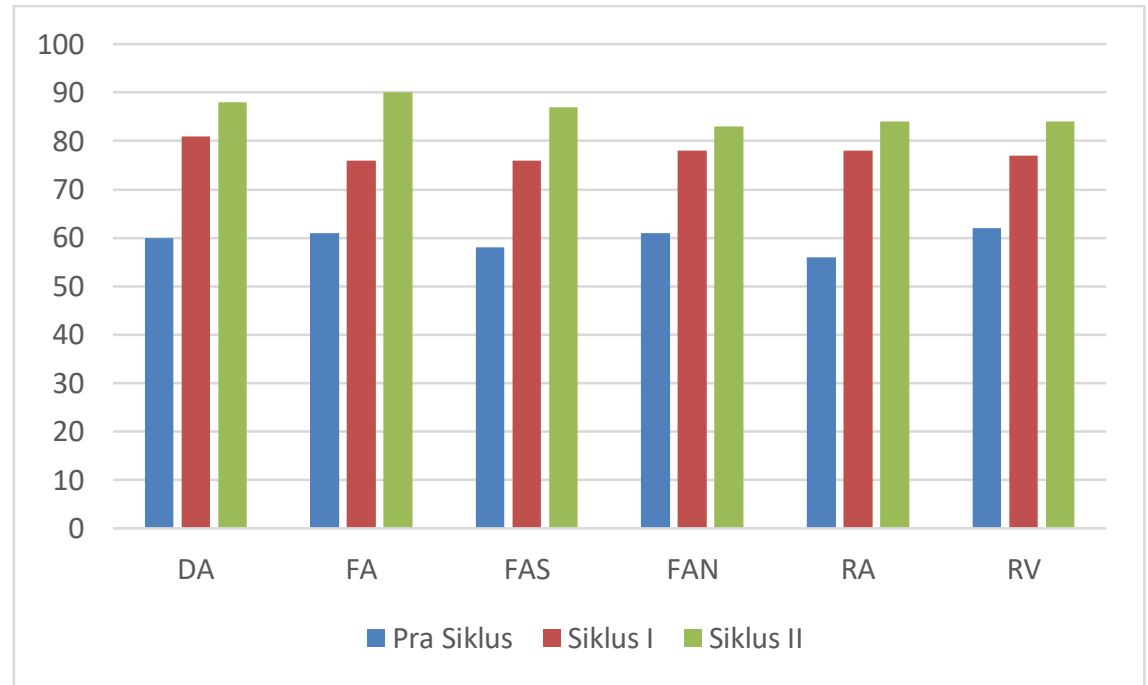

Gambar 1. Grafik Motivasi Belajar Siswa Pada Tahap Pra Siklus, Tahap Siklus I Dan Tahap Siklus II

\section{PEMBAHASAN}

Hasil penelitian ini menunjukkan bahwa konseling singkat berbasis solusi teknik miracle question efektif dan dapat dijadikan sebagai salah satu alternatif intervensi dalam meningkatkan motivasi belajar siswa. Menurut Daki (Daki, 2008) dalam SFBC, masalahmasalah kompleks yang dialami oleh individu dapat dipecahkan atau diselesaikan dengan membantu individu menemukan langkah-langkah kecil dengan arahan yang positif. Sesuai dengan tahapan atau langkah yang diterapkan dalam penelitian ini. Tahap intervensi pertama, subyek penelitian diarahkan untuk mencari hambatan-hambatan dalam kegiatan belajar seharihari sehingga mereka dapat merumuskan strategi dalam mengatasi hambatan-hambatan tersebut sesuai dengan cara yang mereka susun. Strategi yang mereka susun dalam perbaikan sikap belajar dilakukan dengan cara yang menyenangkan, memiliki tujuan, dan dapat meningkatkan motivasi belajarnya. Pada tahap intervensi kedua, peneliti melakukan perbaikan 
dengan memberikan kalimat-kalimat pertanyaan keajaiban (miracle question) untuk mengetahui sejauh mana perbaikan tingkat motivasi belajar yang sudah dicapai oleh subyek penelitian setelah mengikuti intervensi kedua. Dan pemberian penguatan dapat diberikan agar subyek penelitian dapat mempertahankan motivasi belajar yang sudah meningkat.

Penelitian sebelumnya juga membuktikan bahwa penggunaan konseling singkat berbasis solusi dapat meningkatkan motivasi, self esteem dan sikap peserta didik terhadap sekolah (Daki \& Savage, 2010). Penelitian lain juga menyatakan bahwa konseling singkat berbasis solusi memberikan dampak positif terhadap motivasi belajar. Penelitian (Mckergow \& Korman, 2008) menjelaskan bahwa intervensi SFBC dapat merubah beberapa variable seperti kepercayaan, kepribadian, sikap, motivasi, nilai, pemikiran, emosi, jiwa, mental, kelemahan dan kekuatan pada individu. Dalam penelitian tersebut, peneliti mengkaji lebih banyak aspek yang dapat ditingkatkan dengan intervensi SFBC.

Penggunaan Konseling Singkat Berfokus Solusi (SFBC) menurut Corey (Corey, 2016) adalah hakikat manusia yang dinilai positif, memiliki sikap optimis, sehat dan sangat kompeten. SFBC adalah salah satu dari sekian banyak model konseling yang lebih menekankan pada kemampuan kompetensi manusia daripada ketidakmampuannya, dan lebih padakekuatan daripada kelemahan. Setiap individu mampu mencari solusi dari dalam dirinya sendiri dan dapat memperbaiki pola hidupnya. Semua tantangan dan kendala dalam kehidupan dapat diatasi oleh setiap individu. Konselor memiliki suatu kenyakinan bahwa setiap konseli memiliki kemampuan mencari dan menentukan solusi untuk menyelesaikan masalahnya sendiri. Menurut deShazer (dalam Corey, 2016) bahwa dalam menggali informasi berkaitan dengan masalah yang dialami konseli bukan merupakan suatu hal yang penting, yang lebih penting adalah pembentukan kerjasama dengan konseli sehingga konselor dapat membantu konseli lebih fokus dalam mencari dan menggali solusi yang sesuai dengan kemampuan diri konseli untuk mencari jalan keluar dalam menyelesaikan masalahnya. Pada konseling SFBC, konseli memilih tujuan-tujuan yang mereka ingin capai dalam terapi, dan diberikan sedikit perhatian terhadap diagnosis, pembicaraan tentang sejarah, atau eksplorasi masalah (Bertolino \& O'Hanlon, 2002; Gingerich \& Elisengart, 2000; O'Hanlon \& Weiner-Davis, 1989 dalam Corey, 2016).

Teknik konseling SFBC terdapat beberapa ide dasar tentang perubahan, hubungan, dan tujuan yang ingin dicapai. Konselor SFBC meyakini bahwa setiap individu mampu dalam merumuskan dan menetukan tujuan-tujuannya dan setiap individu memiliki kekuatan dalam memecahkan masalahnya. Tujuan-tujuan tersebut memiliki sifat yang unik bagi tiap-tiap konseli dan konseli membuat tujuan-tujuan sendiri untuk merencanakan masa depan yang lebih baik dan memiliki makna (Prochaska \& Norcross, 2007). Menggali banyak hal yang diinginkan oleh konseli merupakan hal yang sangat penting dilakukan di tahap awal pelaksanaan terapi agar konseli (Bertolino \& O'Hanlon, 2002). Membantu konseli untuk mengadopsi pergeseran sikap dan bahasa konseli dari berbicara mengenai permasalahan menjadi berbicara tentang berbagai solusi merupakan tujuan yang paling utama dalam konseling SFBC. Konseli diberi stimulus untuk menceritakan perubahan-perubahan yang ingin dicapai atau solusi daripada berbicara tentang masalahnya. Karena terkadang hal yang disampaikan dapat menjadi sesuatu hasil bagi konseli. Salah satu teknik dalam SFBC adalah miracle questions (pertanyaan ajaib) Konselor 
melakukan kerjasama dengan konseli dalam merumuskan tujuan-tujuan yang disusun secara tepat dan detail sehingga konseli dapat menemukan solusi dengan baik. Usaha mewujudkan peningkatan motivasi belajar peserta didik maka diasumsikan pendekatan SFBC dapat diterapkan karena setiap manusia mempunyai kemampuan dalam mereduksi masalahmasalahnya sendiri. Konseling SFBC tidak memiliki penilaian komfrehensif tentang watak manusia, tetapi lebih fokus pada kemampuan dan kesehatan manusia untuk berubah dan perubahan tersebut tidak dapat dihindari. Tahapan pendekatan SFBC agar dapat digunakan secara maksimal, menurut Seligman (dalam Mulawarman, 2014) adalah sebagai berikut: membangun hubungan baik dengan baik dengan konseli untuk berkolaborasi sehingga membantu konseli membangun solusi, mengidentifikasi permasalahan sehingga bisa ditemukan solusinya, menetapkan tujuan dengan memberikan pertanyaan keajaiban seperti "seandainya kamu memiliki nilai yang baik apa yang akan kamu rasakan?", merancang dan menetapkan intervensi, kemudian ada pengakhiran, evaluasi dan tindak lanjut.

Pemberian bantuan pada seseorang (konseli/peserta didik) dilakukan dalam bentuk kegiatan konseling kelompok. Dalam layanan Bimbingan dan Konseling ada layanan Konseling kelompok. Buku Panduan Pelayanan Bimbingan dan Konseling Berbasis Kompetensi (Mamat:2018) yang dimaksud dengan konseling kelompok adalah: Layanan bimbingan dan konseling yang memungkinkan peserta didik (klien) memperoleh kesempatan untuk pembahasan dan pengentasan permasalahan yang dialaminya melalui dinamika kelompok; masalah yang dibahas itu adalah masalah-masalah pribadi yang di alami oleh masing-masing anggota kelompok. (Prayitno 2013:307) konseling kelompok adalah suatu kegiatan pemberian bantuan dari seorang konselor kepada beberapa konseli untuk mengentaskan suatu masalah dalam suasana dinamika kelompok. Pelaksanaan layanan Konseling kelompok dilakukan dalam empat tahap, yaitu tahap pembentukan, tahap peralihan, tahap pelaksanaan kegiatan dan tahap pengakhiran (Prayitno, 2013). Tahapan-tahapan tersebut merupakan suatu rangkaian yang harus diterapkan dalam pelaksanaan kegiatan konseling kelompok. Pada tahap pembentukan, konselor sebagai pemimpin konseling kelompok harus menyampaikan aturanaturan dalam pelaksanaan konseling yang meliputi pembukaan kegiatan dengan doa, menyampaikan topic bebas agar peserta didik merasa nyaman, perkenalan anggota kelompok, dan pemberian permainan agar peserta lebih rileks dalam mengikuti layanan. Tahap peralihan adalah tahapan dimana pemimpin kelompok harus dapat mengontrol dan mengarahkan anggota kelompok untuk lebih rileks dan terbuka dalam menyampaikan masalahnya. Pendekatan langsung dengan cara memberikan perintah, adalah hal yang harus dihindari oleh seorang pemimpin kelompok. Membantu anggota kelompok untuk menghadapi keengganan, rasa malu, dan sikap pertahanan diri adalah tugas pemimpin kelompok agar tercapai tujuan kelompok. Tahap pelaksanaan kegiatan adalah inti kegiatan layanan konseling kelompok, dimana semua anggota kelompok sudah terjalin hubungan yang baik. Saling tukar pendapat, menyampaikan asumsinya, mempertahankan pendapatnya sehingga pembukaan diri berlangsung dengan bebas dalam dinamika kelompok. Pemimpin kelompok harus melihat dengan baik dan menentukan arah yang dituju dari setiap pembicaraan yang dilakukan anggota kelompok. Tahap pengakhiran adalah tahap terakhir dari kegiatan konseling kelompok, dimana pemimpin kelompok harus membuat kesimpulan dari perilaku-perilaku baru yang diperoleh 
anggota kelompok selama konseling kelompok berlangsung. Umpan balik merupakan hal yang penting untuk menilai dan memperbaiki perilaku kelompok. Oleh karena itu, tahap ini merupakan tahap melatih diri anggota kelompok untuk melakukan perubahan sesuai tujuan yang ingin dicapai.

Penelitian ini dilaksanakan dalam waktu yang singkat, sehingga peneliti belum memberikan follow up terhadap intervensi yang sudah dilakukan untuk meningkatkan motivasi belajar siswa. Pertanyaan mendasar yang mungkin muncul adalah sejauh mana efek intervensi ini bertahan pada subyek penelitian. Untuk memastikan ketahanan efek meningkatnya motivasi belajar maka diperlukan evaluasi secara kontinyu yang dilakukan peneliti berkoordinasi dengan wali kelas dan juga guru mata pelajaran.

\section{KESIMPULAN DAN SARAN}

Ada peningkatan motivasi belajar pada subyek penelitian setelah mengikuti layanan konseling kelompok dengan pendekatan SFBC teknik miracle question. Perubahan pada peserta didik adalah peningkatan motivasi belajar yang lebih positif seperti tertib mengerjakan tugas, mengikuti kegiatan belajar tepat waktu, aktif dalam kegiatan belajar, dan membagi waktu antara belajar dengan bermain game. Sehingga dapat diambil kesimpulan bahwa layanan konseling kelompok pendekatan SFBC teknik miracle question dapat meningkatkan motivasi belajar siswa kelas XI IPA 2 SMA Hang Tuah 1 Surabaya. Konselor mengupayakan untuk melakukan penelitian-penelitian yang lain agar dapat menggali kendala-kendala dan masalah yang dialami peserta didiknya sehingga dapat membantu peserta didik mengentaskan masalah-masalahnya dengan menerapkan strategi konseling yang tepat. Konselor dalam memberikan layanan harus komunikatif, mempergunakan media yang variatif dan inovatif agar peserta didik memberikan respon yang baik dengan selalu tertarik dan tidak mengalami kebosanan mengikuti kegiatan belajar, dengan memberikan layanan yang menarik merupakan salah satu cara menumbuhkan motivasi belajar peserta didik. Konselor harus selalu belajar untuk mengembangkan diri, memperluas refensi sumber belajar, pelatihan, mengikuti workshop dan kegiatan pengembangan keprofesionalan lainnya sehingga dapat memperbaiki kualitas diri untuk melaksanakan kegiatan layanan yang sesuai dengan ketentuan profesional. Bagi para stakeholder, pemenuhan fasilitas merupakan hal yang dibutuhkan untuk suksesnya suatu kegiatan, memberikan pelatihan yang sesuai dengan kebutuhan dan tuntutan jaman, melaksanakan kegiatan untuk menunjang pengembangan profesi guru. Bagi penelitianpenilitian selanjutnya, mampu bekerja secara profesional, menggali banyak hal-hal baru yang hasilnya nanti akan memberi sumbangan manfaat bagi perbaikan mutu pendidikan.

\section{DAFTAR RUJUKAN}

A.M, Sardiman. 2011. Interaksi dan Motivasi Belajar-Mengajar. Jakarta:PT Raja Grafindo Persada

Bertolino, Bob A., \& O' Hanlon, Bill. 2002. Collaborative, Competency-Based Counseling and Therapy. Boston: Allyn and Bacon

Corey, G. 2016. Theory and Practice of Counseling and Psychotherapy (9thed). Belmont: Brooks/Cole 
Daki, J. 2008. Solution Focused Brief Therapy: Addresing Academic, Motivational, Social and Emotional Difficulties of Older Children with Reading Deficits McGill University, Montreal.

Daki, J., \& Savage, R. S. 2010. Solution Focused Brief Therapy: Impacts on Academic and Emotional Difficulties. The Journal of Educational Research, 103, 309-326. https://doi.org/10.1080/00220670903383127

Djamarah, Syaiful Bahri. 2011. Psikologi Belajar. Jakarta: Rineka Cipta

Hopkins, David. 2011. Panduan Guru Desain Penelitian Tindakan Kelas. Yogjakarta: Pustaka Belajar

Mckergow, M., \& Korman, H. 2009. Inbetween-Neither Inside Nor Outside: The Radical Simplicity of Solution-Focused Brief Therapy. Journal of Systematic Therapies, 28 (2), $34-49$

Mulawarman. 2014. Brief Counseling in Schools: A Solution-Focused Brief Counseling (SFBC) Approach for School Counselor in Indonesia. Journal of Education and Practice, 5(21): 68-72

Omrood, Jeanne Ellis. 2010. Psikologi Pendidikan Membantu Siswa Tumbuh dan Berkembang. Jakarta: Erlangga

Prayitno. 2013. Seri Panduan Layanan dan Kegiatan Pendukung Konseling. Padang: BK FIP UNP

Prayitno dan Erman Anti, 2004. Dasar-dasar Bimbingan dan Konseling: Rineka Cipta, Jakarta

Prochaska. J. O., \& Norcross, J. C. 2007. System of psychotherapy: A transtheoretical analysis (6 $6^{\text {th }}$ ed). Belmont, CA: Wardsworth.

Rahmadian, A.A. 2011. Kreativitas dalam Konseling. Makalah Disajikan Pada Seminar Internasional Impact Counseling. Bandung: Universitas Pendidikan Indonesia (UPI)

Supriatna, Mamat. 2018. Bimbingan dan Konseling Berbasis Kompetensi. Jakarta: Raja Grafindo Persada 